Article

\title{
"A Good Place for the Poor!" Counternarratives to Territorial Stigmatisation from Two Informal Settlements in Dhaka
}

\author{
Kazi Nazrul Fattah * and Peter Walters \\ School of Social Science, The University of Queensland, St Lucia, QLD 4072, Australia; E-Mails: k.fattah@uq.edu.au (K.N.F.), \\ p.walters@uq.edu.au (P.W.) \\ * Corresponding author
}

Submitted: 28 August 2019 | Accepted: 4 October 2019 | Published: 27 February 2020

\begin{abstract}
With many cities in the Global South experiencing immense growth in informal settlements, city authorities frequently try to assert control over these settlements and their inhabitants through coercive measures such as threats of eviction, exclusion, blocked access to services and other forms of structural violence. Such coercive control is legitimized through the discursive formation of informal settlements as criminal and unsanitary, and of the residents as migrants and as temporary and illegitimate settlers. Using findings from ethnographic research carried out in two informal settlements in Dhaka, Bangladesh, this article explores how informal settlement residents engage with and resist territorial stigma in a rapidly growing Southern megacity. Findings show residents resist stigmatising narratives of neighbourhood blame by constructing counternarratives that frame informal settlements as a "good place for the poor." These place-based narratives emerge from shared experiences of informality and associational life in a city where such populations are needed yet unwanted. While residents of these neighbourhoods are acutely aware of the temporariness and illegality of unauthorised settlements, these narratives produce solidarities to resist eviction and serve to legitimise their claim to the city.
\end{abstract}

\section{Keywords}

counternarratives; Dhaka; informal settlements; megacity; territorial stigma

\section{Issue}

This article is part of the issue "New Research on Housing and Territorial Stigma" edited by Margarethe Kusenbach (University of South Florida, USA) and Peer Smets (Vrije Universiteit Amsterdam, the Netherlands).

(C) 2020 by the authors; licensee Cogitatio (Lisbon, Portugal). This article is licensed under a Creative Commons Attribution 4.0 International License (CC BY).

\section{Introduction}

Across the world, one in every four urban dwellers now lives in some form of informal settlement (UN-Habitat, 2015). These settlements, commonly referred to as ghettoes, slums, refugee camps or squatter settlements, comprise the majority of the urban population in many megacities of the Global South and are a vital part of the economy and social life of those cities. Yet, residents of such neighbourhoods are invariably marked by a stigma of place that affects their relationship with the wider city, their life chances and sense of collective self (Smith, 2010; Wacquant, 2007). In cities segregated by the unequal geographies of formal and informal, such territorial stigma serves as an instrument to maintain hegemonic control through actively producing and reproducing geographies of difference and maintaining spatial and social division (Ingen, Sharpe, \& Lashua, 2018). Territorial stigmatisation is a form of violence from above deployed by urban elites to sustain relations of power and domination, and legitimise reproduction of social inequalities and injustices (Tyler, 2013; Wacquant, 2008). Discourses of vilification consisting of deeply discrediting narratives that circulate in political, bureaucratic and journalistic fields produce the dominant imaginings of urban poor neighbourhoods (Butler, 2019; Parker \& Karner, 2010; Wacquant, 2008). Such narratives portray informal settlement residents as undesirable in the city, and systematically exclude them from essential urban amenities and opportunities in- 
cluding access to employment, education, and medical care (Keene \& Padilla, 2014). Through territorial stigmatisation informal settlement residents become an "obnoxious and repugnant other, always underserving and tainted" (Auyero, 1999, p. 65), an out-of-place population to be removed from the city.

There has been considerable interest in academia about how territorial stigma is produced and how people living in stigmatised places cope with it. However, the primary focus has been on stigmatised places in cities in North America and Europe. In comparison, this issue is comparatively less explored in the context of Southern cities. In this article we introduce an ethnographic study carried out in two informal settlements in the megacity of Dhaka, Bangladesh, to highlight the ways in which residents of such neighbourhoods understand the stigmatising discourses used against them, and how they in turn construct more positive and productive discourses about their own neighbourhoods.

By focusing on informal settlements in Dhaka we aim to contribute to the growing literature on territorial stigma and broaden the understanding of the issue in the context of the Global South. We argue that while residents are aware of the illegality and temporariness of their neighbourhoods and internalise stigmatised identities, they also produce various counternarratives to present a different view of their neighbourhoods. These counternarratives challenge dominant discourses and work to legitimise informal settlement residents' claim to the city. In this article, first, we will review key literature on territorial stigma from the Global North and the South. We will then introduce the study sites and discuss the methods used in the study. Following this, we will describe the dominant discourses on informal settlements in Dhaka and how these discourses are used to rationalise the state's use of coercive power over residents. Drawing on participant accounts we will then elaborate on how the residents of the two neighbourhoods experience and contest territorial stigma. Finally, we will conclude by emphasising the importance of recognising the counternarratives produced by urban informal settlement residents.

\section{Managing Spatial Stigma}

According to Goffman (1963), for the stigmatised, identity management is a key strategy for coping with and managing the effects of stigma. Goffman's conceptualisation of stigma along with Bourdieu's theory of symbolic power serve as foundational basis for Wacquant's $(2007,2008)$ theoretical framework of territorial stigma which provides critical insight for understanding how people living in defamed housing settlements manage and cope with stigma. In the case of territorial stigma, studies carried out in cities of the Global North show a range of identity management strategies used by the residents of discredited neighbourhoods/suburbs. To cope with stigma and construct positive identities they often physically and symbolically distance themselves from their neighbours and the neighbourhood (Wacquant, 2008). When people from outside a neighbourhood/suburb stigmatise residents, at times, they will hide their address in an attempt to dissociate themselves from the stigma. They may avoid having relatives or friends visit their home (Palmer, Ziersch, Arthurson, \& Baum, 2004; Wacquant, 2007; Warr, 2016). Some residents accept the criminalising narratives of their neighbourhood and constantly isolate themselves from others (Blokland, 2008; Osborne, Ziersch, \& Baum, 2011; Warr, 2016). Residents who internalise stigmatising narratives frequently use lateral denigration, reproducing a faceless stigmatised other-usually a certain group of people or areas within the neighbourhood-and thrust the stigma onto a demonised other (Blokland, 2008; Popay et al., 2003; Wacquant, 2007) by producing 'micro-differences' (August, 2014; Thomas, 2016). Even when residents do not internalise the stigmatising narratives themselves, they may internalise an awareness of the stigma imposed on their neighbourhood (Jensen \& Christensen, 2012). Residents' response to territorial stigma, however, is not limited to submission and internalisation (Hastings, 2004; Jensen \& Christensen, 2012). Stigma can be "negotiated and resisted in everyday lives" (Tyler \& Slater, 2018, p. 735). As studies show, in many discredited neighbourhoods, residents resist stigma through self-affirmation, sense of belonging and community, and pride of place (Jensen \& Christensen, 2012; Slater, 2017; Slater \& Anderson, 2012).

In comparison to the global North, a relatively small number of studies have explored the issue in Southern cities. These studies, many of which examined the experience of territorial stigma by favela residents in Brazil, revealed similar accounts of internalisation of stigma (Araújo \& Costa, 2017; Auyero, 1999; Caldeira, 2000; Gama, 2018) as did studies in Botswana (Geiselhart, 2017), China (Zhang, 2017) and India (Ghertner, 2010). In many neighbourhoods deflecting stigma to other residents was common as well (Auyero, 1999; Gama, 2018). When residents talked about other residents "a certain suspicion was always expressed, in ambiguous ways" (Caldeira, 2000, p. 79). Despite this, residents of stigmatised settlements also present a somewhat different insider view of the place where they live. These insider narratives indicate community, friendship, and belonging that result from the shared experiences of everyday life (Geiselhart, 2017; Zhang, 2017). Be it in a neoliberal city of the Global North or a 'developing' or 'emerging' city in the Global South, insider narratives by residents of discredited neighbourhoods offer important insight for understanding how they manage and contest territorial stigma. Building on the work discussed here, we now turn to Dhaka, one of the fastest growing megacities in the Global South, to examine insider views of residents from two informal settlements and understand how they engage with neighbourhood stigma and resist the dominant discourses. 


\section{Methods}

In this article, we present ethnographic accounts from fieldwork carried out in two informal settlements in Dhaka over a period of seven months in 2017. Our first study site, Korail, is home to nearly 100,000 people living on approximately 90 acres of public land. Located next to two of the most affluent urban enclaves in the city, it is the largest informal settlement in Dhaka. Our second study site, Town Hall Camp, is surrounded by a middleclass suburb in a different part of the city. It is a densely packed neighbourhood where approximately 5,000 people live on barely one acre of land. Figure 1 shows the locations of Korail and Town Hall Camp in Dhaka city.

Korail residents mostly consist of rural migrants who came to Dhaka from different parts of the country in search of work. Unable to find affordable housing in the city they started to build makeshift houses at Banani lakeside during the latter part of the 1980s, which gradually became the massive settlement it is today. As residents do not have legal claim to this land, Korail is considered by the city authorities as an illegal settlement. Town Hall Camp is one of the 30 Bihari camps in Dhaka that were set up during 1972-1973 to accommodate Bihari refugees. In recent years many rural migrants have also moved into the camp due to low rents. Biharis are an ethnic minority community consisting of Muslim refugees who originally migrated from Bihar and the surrounding states of India. They have been subject to continued state discrimination and deprivation due to their stance against Bangladesh's independence in 1971. Residents of informal settlements like Korail and Town Hall Camp constitute the majority of the informal sector workers in Dhaka. Apart from a handful of affluent local leaders and businessmen, they are mostly poor and make a living from low wage, low skilled and labour-intensive work (e.g., rickshaw pullers, street vendors, housemaids, cleaners, day labourers, and transportation workers).

Findings presented here are drawn from field notes from participant observation in Korail and Town Hall Camp as well as numerous informal conversations with the residents of these neighbourhoods. 46 in-depth interviews (28 in Korail and 18 in Town Hall Camp) and two focus group discussions (one in each study site) were also carried out with the residents. Interview participants were selected purposively and included general residents, community-based organisation members, and local social and political leaders (female $=22$, male $=24$, ages ranging from 18 to 65 ). The semi-structured interviews explored residents' everyday life experiences of living in an informal settlement and their modes of engagement with various formal and informal state and nonstate actors. The average duration of interviews was one hour. Additionally, eight in-depth interviews were carried out with non-government organisation (NGO) and local government officials (male $=8$, ages ranging from

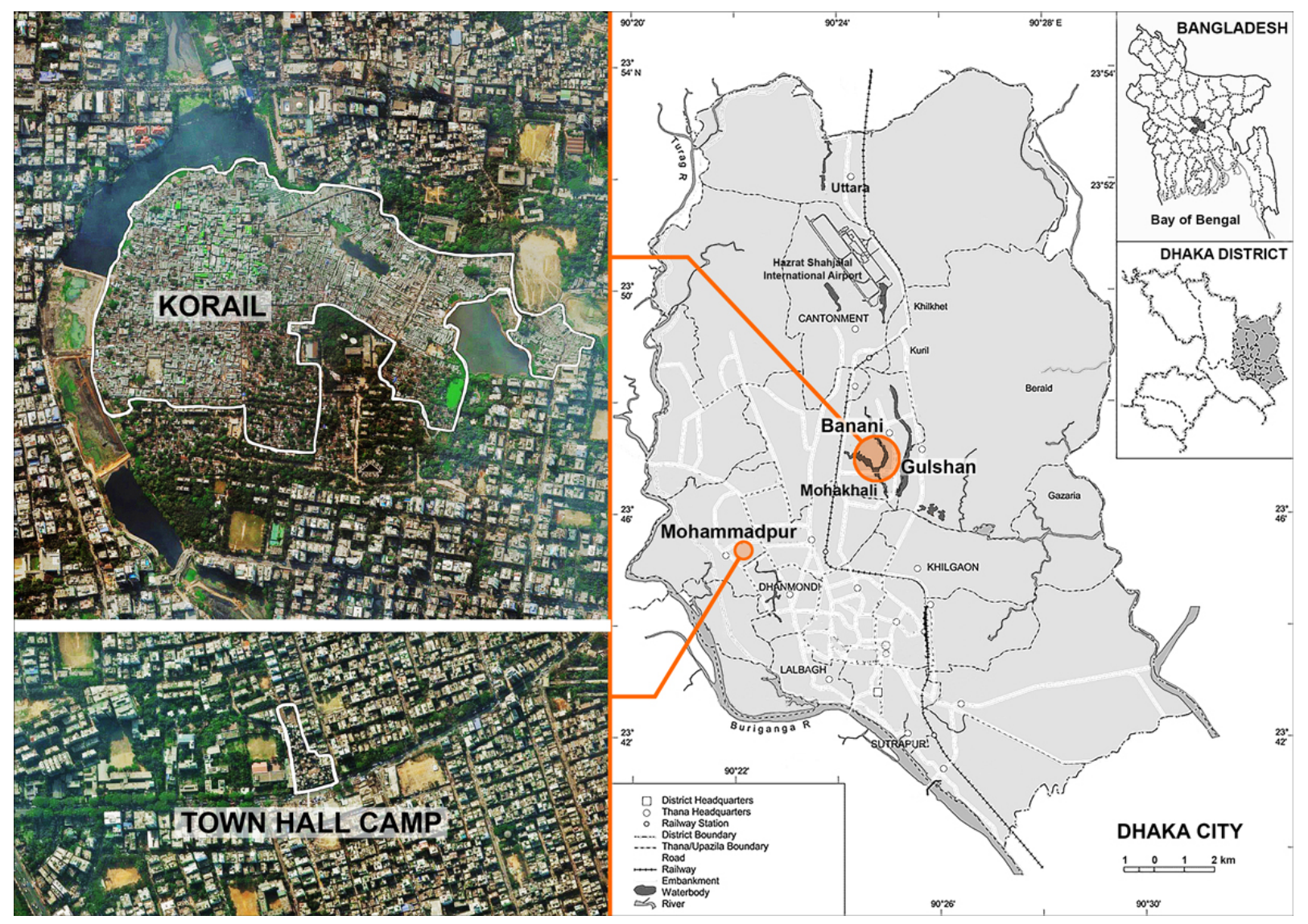

Figure 1. Map of Dhaka city showing study sites. Source: Worldmap (n.d.) and Google Maps. 
30 to 60 ). All interviews were conducted in Bengali by the first author. They were audio recorded except for a few cases where participants did not want to be recorded. The interviews were transcribed in Bengali to ensure authenticity of data and only selected quotes were translated to English after data analysis. An inductive thematic analysis approach was used to make sense of the data and find key themes (Creswell, 2007). Pseudonyms were used for all participants in the article.

\subsection{A Note on Terminology}

We used 'informal settlements' as a neutral term for lowincome settlements instead of contested terms such as 'slum,' 'ghetto,' or squatter settlement. While presenting participant accounts, and in some other instances, we used bosti-the local Bengali term for such settlements. Instead of the more widely used spellings such as basti, baste or bustee, we chose bosti following Hossain (2013), as it is closer to the way participants in the study sites pronounced the word. Also, we acknowledge the contested nature of the term 'Global South' (Dados \& Connell, 2012). We identify Dhaka as a 'Southern' city, which allows us to locate the city in its postcolonial present where differential economic and social structures and processes maintain "large inequalities in living standards, life expectancy, and access to resources" (Dados \& Connell, 2012, p. 13).

\section{Territorial Stigmatisation of Informal Settlements in Dhaka}

Dhaka's emergence as a megacity is largely due to the massive influx of rural migrants since the 1980s. According to various estimates around $30 \%$ of the city's nearly 18 million people live in some 4,000 unplanned and unauthorised housing settlements often referred to as 'slums' and camps (Ahmed, 2014). Rural to urban migration is a feature in the growth of many megacities in the Global South as labour moves from stagnant or mechanised rural farming sector into modernising urban economies. The social contours of these migrations differ. In Dhaka, rural migrants tend to gravitate to rural kinship groups who have established themselves in the city, resulting in concentrations of strong but inwardlooking communities in many informal settlements (Lata, Walters, \& Roitman, 2019).

People living in informal settlements make significant contributions to the gross domestic product (GDP) by serving as a major source of cheap labour (Rahman, 2012). They make possible the production of goods for export to developed countries at a globally competitive price and also provide low cost services and products to city dwellers (Bork-Hüffer et al., 2016; Rahman, 2012). Informal settlement residents are closely tied to the economic and political interests of the national government, city authorities, urban elites and middle classes. However, while the city relies on informal settlement residents for survival and continued growth, in their aspiration for a modern and developed city, urban elites and middle classes find them incompatible with the city's vision. This is obvious in the works of authors such as Siddiqui et al. (2010, p. 15) who condemn informal settlements for making Dhaka city "a most dismal spectacle." Informal settlement residents in Dhaka thus find themselves in a complex relationship with a city where they are needed, yet unwanted.

City authorities often seek to address the complex challenge informal settlements pose to urban governance, policy and planning practices by using violence and repression. While they allow these neighbourhoods to continue and even to flourish, they frequently use coercive power to assert control and authority over them. This phenomenon is not unique to Dhaka. Coercive power is used by state apparatuses in the form of constant threats of eviction, blocked access to services and resources, non-recognition as rightful residents of the city, frequent criminalisation and structural violence to shape the everyday life experiences of informal settlement residents across many cities in the Global South (Bhan, 2014; Bork-Hüffer et al., 2016; Moser, 2004; Sanyal, 2014). Acts of violence and repression are rationalised by designating these neighbourhoods and their residents as an undesirable other and a threat to the 'ordered' city. As Wacquant (2007, p. 69) noted: “Once a place is publicly labelled as a 'lawless zone' or 'outlaw estate,' outside the common norm, it is easy for the authorities to justify special measures, deviating from both law and custom."

The most common portrayal of informal settlements in Dhaka is that they are illegal, or 'slums' unlawfully constructed on public land (Bertuzzo, 2016; Suykens, 2017). The residents are frequently referred to as 'land grabbers' and 'encroachers.' By unlawfully 'encroaching' and 'occupying' land they have become illegal. We interviewed Mr. Lokman, an elected local government official (Ward Councillor) whose seat was secured thanks to a large number of votes from Korail residents in 2015. He immediately pointed out their illegality: "Does anyone in Korail live there legally?...All of them are illegal."

Mainstream media plays a key role in presenting informal settlements as hotspots of crime, reinforcing narratives that criminalize the urban poor (e.g., Hasan, 2018; Khan, 2013; Mahmud, 2018). A popular television crime show called Taalash ('search') that aired on prime time during 2013-2014 used the term 'crime factory' to emphasize that the informal settlements are a source of criminality and lawlessness. In 2016, when a group of Islamist extremists carried out a deadly terrorist attack at a restaurant in Gulshan claiming 29 lives, fingers were immediately pointed at Korail as a possible breeding ground for such extremists. Although none of the people involved in the attack were found to have any connections with Korail, law enforcement agencies took measures that severely restricted the mobility of Korail residents. This involved shutting down boat trans- 
portation on Banani Lake which was the most convenient and affordable way for Korail residents to commute between Korail and the adjacent Banani and Gulshan areas where they worked. Strict restrictions were imposed on rickshaw pullers who worked in Banani and Gulshan. Heightened security measures resulted in many rickshaw pullers from Korail being unable to work in these two areas. Some of them had to move to other parts of the city in search of livelihoods.

Discourses of environmental degradation add to the narratives of criminality by highlighting unsanitary living conditions and pollution, and present informal settlements as a public health risk (Jahan, 2012). Also, though many informal settlement residents have been living in the city for decades, they are still viewed as migrants, and identified with distant rural areas from where they or their parents arrived (Local Government Division, 2014; Siddiqui et al., 2010). Moreover, NGOs working in the urban space present informal settlements as a manifestation of underdevelopment by selectively highlighting residents' low literacy, poverty and unemployment (Hossain, 2013). Through their very mandate of 'improving' these neighbourhoods, NGOs also take part in the process of stigmatising them.

Ethnicity plays a significant role in the process of territorial stigmatisation (Jensen \& Christensen, 2012). For the residents of Bihari camps, the burden of stigma is intensified in manifold ways due to their ethnic identity. They are frequently identified as non-citizens despite having national identity cards and regularly casting votes in local and national elections. Mainstream media refers to them either as Bihari refugees or stranded Pakistanis which strengthens the narratives of stigmatisation and creates grounds for discrimination. Babu, a young man from Town Hall Camp, described the differential treatment Biharis received outside the camp: "'They are from the camp-Biharis!' At once we become something different in the eyes of everyone. We become separate!" Additionally, Bihari camps are frequently identified as 'dirty' and unsanitary places that are hotspots of drug dealing and petty crimes.

As in many other rapidly growing megacities in the Global South (Ghertner, 2008; Ong, 2011), Dhaka's elite and middle classes identify informal settlements as incompatible with the idea of becoming a modern and developed city. With steady economic growth in Bangladesh and a state-produced aspiration to become a middle-income country by the middle of the next decade, they indulge in a mass vision of a 'slum' free city with no place for informal settlements.

\section{Managing and Countering Stigma in Korail and Town Hall Camp}

The subjective accounts of those living in stigmatised neighbourhoods are likely to be different from the accounts of those who live outside such neighbourhoods and subscribe to the discourses of stigmatisation. To un- derstand how residents of stigmatised neighbourhoods engage with socio-spatial stigma it is necessary to focus on how they experience and reflexively interpret everyday life as insiders (Warr, 2005). The everyday modalities of living with and managing neighbourhood stigma is also influenced by the socio-economic and historical contexts of the place and the people. The insider accounts presented below show that in Korail and Town Hall Camp, the residents internalised certain stigmatising discourses and consciously attempted to differentiate their neighbourhood from other informal settlements in the city. However, they also resisted the stigmatising narratives by producing various counternarratives that presented these neighbourhoods as good places to live, but only for the poor.

\subsection{Internalising and Deflecting Stigma}

People living in stigmatised places can very well "reproduce and reinscribe majoritarian stories and master narratives" (Muñoz \& Maldonado, 2012, p. 296). In Korail and Town Hall Camp, many residents internalised the meanings of the stigmatising narratives of informal settlements. Through internalisation of the discourses of legality and illegality they accepted themselves as illegal and/or temporary residents in the city. Moreover, they recognised this illegality/temporariness as a justification for the government's intention to evict them. In Korail, Ataur, an unemployed transport worker in his sixties, remarked: "This is public land, we are living here illegally." Mofizur, a man in his early forties who worked as a support staff for a local TV station and lived in Korail for more than 20 years, expressed similar views: "This place is illegal. The government did not allocate it to us or anything like that. That's why the government is not building anything here." In Town Hall Camp, despite having citizenship documents, several participants believed that they were "refugees" because the state viewed them as such.

Internalisation of the discourse of illegality was particularly common among younger participants in Korail. These internalisations run so deep that some participants even justified being searched by police on their way in or out of the neighbourhood or at the security checkpost set up at the entrance of Banani, an upscale neighbourhood next to Korail. Shiuli, an undergraduate student and primary school teacher, thought it was okay for the police to stop and search her and her friends when entering Banani from Korail:

Some days ago, my friends and I were going there and then they stopped us [at the checkpost]. They asked to search our bags.... appreciated that they did this. This should be done, because there are many different types of people. We were going there with good intentions. Some people might have bad intentions.

Hasan, another undergraduate student who moved to Korail about six years ago from his hometown, was 
stopped by the police one evening on his way out of Korail. He had a high fever and was going back to his hometown to stay with his parents until he got better. Though he informed the police that he was ill, they took a long time to search his bag, which he found to be very stressful. Despite this he thought such activities by the police were necessary:

I do not think conducting searches is bad....Even a decent person like me could be involved with different types of crime. It is not unusual. In Dhaka city, if there are crimes [taking place] or militants [living] in a flat, why wouldn't they be in a place like a bosti?

Such internalisations normalise the securitisation of informal settlements by the state and perpetuate the criminalising discourses of these places. Consequently, discriminatory acts such as targeted security checks, stopand-search procedures become normalised as part of the routines of Korail residents' everyday life.

However, both in Korail and Town Hall Camp, participants consistently dissociated their neighbourhood from the dominant imaginings of informal settlements. They emphasised that their neighbourhood was not like the other bostis or camps. In Korail, participants often commented that various types of criminal activity such as drug dealing, mugging and brawls may take place in some other bosti in Dhaka, but not in Korail. Shahadat, a security guard appointed by a local residents' association to patrol the neighbourhood at night, remarked:

Nowadays crimes or illegal activities do not take place in Korail. There was a time when those happened a lot but now it is very rare.....Korail is now a safe neighbourhood, safer than many other neighbourhoods. Even in those neighbourhoods a lot of bad things happen. But not in Korail.

The need to have privately recruited security guards to patrol the neighbourhood, however, contradicted Shahadat's claims. Reports of drug raids in Korail also appeared quite frequently in the newspapers (Mahmud, 2018). Nevertheless, participants repeatedly used words such as "different," "more developed," and "better" to differentiate Korail from other informal settlements. Through such discursive distancing from other bostis, the residents of Korail tacitly accepted the stigmatised construction of informal settlements and simultaneously deflected the stigma to other neighbourhoods. While doing so they simply referred to unnamed bostis in the city by saying, "a few bostis might be like that" or "probably happens in just one or two bostis."

In a similar manner, Town Hall Camp residents claimed that their camp was "cleaner" and "better managed" than other camps and was also "free of drugs." Such claims reflected a similar sense of "collective pride in the neighbourhood, often in response to external defamation," that Slater and Anderson (2012, p. 540) observed in a stigmatised neighbourhood in Bristol. As Monir, an elderly man who lived in the camp since it was established in 1972, said, "There are camps everywhere. But no other camps are as nice as this one-Dhaka's Town Hall Camp!"

Camp residents often deflected the stigma of place onto bostis and described their camp using expressions such as "this is not a bosti" or "a camp is not the same as a bosti." As Sanyal (2014) noted, camps that have existed for many years can gradually begin to resemble 'slums' which is also the case with the Bihari camps in Dhaka. To an outsider the Town Hall Camp appears no different from a bosti. However, several participants emphasised that it should not be viewed as a bosti because camps are not as 'bad' as bostis. Julekha, a small grocery shop owner who lived in the camp since its establishment, commented: "If you call me a stranded Pakistani that is alright. But you cannot call this place a bosti. I will not take that." Some of the participants in Town Hall Camp were not comfortable even with the camp identity of their neighbourhood. One of them, Jamila, an honours student who also worked as an administrative assistant at a business firm in a neighbouring upscale area, explained:

Our camp is a camp only in the name, not in the way things work here. That means there are no illegal dealings, fighting or quarrelling, no stabbing each other, no police business or drug dealing here-nothing of that sort. So, what we have here is not really a camp.

Town Hall Camp residents frequently blamed a nearby Bihari camp with a reputation for open sales of drugs for giving a bad name to all camps. During fieldwork in Town Hall Camp, however, it was not uncommon to randomly come across small groups of young men smoking marijuana on roof tops or in secluded corners, contradicting residents' accounts.

\subsection{Countering Stigma}

Residents' reflexive understanding of everyday life experiences in Korail and Town Hall Camp are characterised by simultaneous acceptance and rejection of the dominant discourses of neighbourhood stigma. They not only internalised such discourses but also resisted them. They did so by producing their own narratives of the place where they lived. These counternarratives 'answer back' (Clarke, Newman, Smith, Vidler, \& Westmarland, 2007) to the dominant narratives with a sharply contrasting internal image that highlights certain aspects of informal settlements which make these neighbourhoods liveable for the urban poor. Using such internal images of Korail and Town Hall Camp the residents produced their own narratives that constantly challenge the dominant narratives of informal settlements. These counternarratives emerge as resistance against "an oppressive identity and attempts to replace it with one that commands respect" (Lindemann, 2001, p. 6) by discursively con- 
structing Korail and Town Hall Camp as 'good' neighbourhoods for the urban poor.

Many of these narratives are based on a 'before and now' comparison, where once conditions in the neighbourhood were bad, but had now changed for the better. As Aziz, a local leader in Korail, commented: "Many of the things you heard about Korail were there. They were there in the past. Things have changed now. You will not find those here anymore." Similarly, in Town Hall Camp, Foyez, a street vendor who sold shoes from a cart in a nearby bazaar, said: "Things are a lot better now. When so many people live together there's bound to be problems....It used to be really bad. But that was before." Both Aziz and Foyez had lived in their respective neighbourhoods since they were children and grew up there. Bilkis, in her fifties, head of a community-based organisation, shared similar views and gave another example:

We used to lag behind in education-Our children didn't study that much. But now, I am telling you, several thousand students from Korail are studying in different colleges....We live in a bosti, yet we are studying, and getting involved with different types of work.

The idea of a good place for the poor in the city was firmly grounded on the possibility of affordable living. Accommodation was much cheaper in a bosti or a camp. According to Foyez: "Outside the rent is 6,000 or 8,000 [takas]. But in the camp, you can pay $4,000,3,000$ or even 2,000 [takas]" (1,000 Bangladeshi takas = 11.76 US dollars).

Affordable living was also about cheaper daily essentials. In the large bazaar inside Korail many of the commodities were sold cheaper than in the markets set up/authorised by the city corporation. Some of the vendors there collected rejected vegetables from the city's wholesale market and sold them in Korail much cheaper. Aziz informed: "When one part of a vegetable goes bad, they cut it off and sell the rest here. You can buy it very cheap." Town Hall Camp too had a small makeshift bazaar where prices of commodities were cheaper than outside. Participants from the camp drew attention to the increasing number of Bengalis living there for cheaper rent, which to them was another indication that the camp was not a bad place to live. In Korail, participants spoke about how inexpensive or free education and healthcare services provided by NGOs made life more affordable. Hasina, a young community organiser in Korail, remarked: "You can get free treatment here. If someone has a serious illness, we can get help by asking an NGO. Nowadays there are advantages-many advantages."

A view commonly shared by participants in Korail and Town Hall Camp was that being free of crime and drugs made a neighbourhood a good place. Their claims about an absence of drugs and crime also served to refute the dominant imaginings associated with these issues. Participants in Korail in particular often argued that so far, law enforcement agencies had found no militants in any of the bostis in Dhaka. The fact that the deadly terrorist attack in Gulshan in 2016 involved men from very well-off families gave further grounds for them to claim that they were unfairly blamed for crimes committed by the rich. As Bilkis explained:

There was a time when the very word bosti made one think about a place where criminals live, where drugs are sold....Yes, there might be one or two [persons] like that but there is good and bad everywhere. It doesn't mean that everyone living in the bosti are criminals....They used to say all the violence is in the bostis. But now you can see it happening in well-off neighbourhoods like Gulshan, Banani, Baridhara.

In both sites, at the beginning of an interview or informal conversation, participants often spoke about overcrowding and their dislike of the frequent quarrels around them. As the conversation progressed, gradually they pointed out things that they liked about their neighbourhood. Common among these were a sense of community, belonging and attachment to place. This played an important role in constructing the narrative of a good neighbourhood. Several participants said that unlike the city's affluent neighbourhoods where no one knows anyone, people in Korail and Town Hall Camp knew and looked after each other. Particularly in Town Hall Camp, everyone literally seemed to know everyone. In Korail, even if the residents didn't know many people from different neighbourhoods, they knew each other within the smaller neighbourhoods. Later in the interview many of the participants rationalised the never-ending quarrels they complained about earlier by saying that such things were bound to happen when so many people lived in such a small area. According to participants, despite having numerous problems they all lived together as a community and neighbours always came to aid when someone was in trouble. As Foyez said:

Suppose the father and mother works outside. They do not have to worry about who will look after their children when they are at work. Some neighbours will look after them. If something happens to a child someone or other from the camp will take them to a hospital and get everything taken care of.

Such community cohesion is rooted in the associational life in informal settlements that relies on social networks and kinship relations, and the shared experiences of struggles against state deprivation, oppression and structural violence. In contrast to outsider narratives of deplorable living conditions in informal settlements, many residents speak about residential satisfaction and place attachments (August, 2014; Jensen \& Christensen, 2012). In Korail or Town Hall Camp, not everyone lived there because of they could not afford to live outside. Many of them continued to live in these settlements because they had developed an attachment to their neighbour- 
hood and neighbours. For example, Hasina who lived in Korail for more than 20 years, described the closeness she felt to the neighbourhood:

I like it here. Been living here for so long, I feel a closeness to it. I do not feel this much attached even to my village. That is where I am from, but I do not feel any attachment to that place. I feel it here.... Here I have my neighbours, I have everyone.

There were many other elements that made up the counternarrative of a good place. Living in Korail or Town Hall Camp allowed ample livelihood opportunities inside the settlement and neighbouring areas. Participants described the people in their neighbourhood as decent and hardworking, commenting that the neighbouring affluent suburbs were dependent on them for their labour and services. Such claims refuted the idea of Korail or Town Hall Camp residents as criminals or unworthy residents of the city and instead presented them as a group of hardworking people who were serving the city's needs. These micro-narratives and many others produced a shared understanding of a good place to live in the city.

Of course, people living in these neighbourhoods were keenly aware of their socio-political reality and highlighted many problems for example insecurity of tenure, absence of paved roads, barred access to utilities, and harassment by police. When they claimed their neighbourhood to be a good place, they immediately added that it was good for people who could not afford to live anywhere else in the city. As Shabana, one of the first to settle in Korail, commented:

Life in Korail is more or less good for us. We are poor so it's good for us, because we cannot afford to live anywhere else as the rent is high....The advantages that people have living here, they wouldn't get those anywhere else.

Similarly, in Town Hall Camp, residents were well aware that there was no scope for romanticising the camp as an ideal place to live. They made it clear that the camp was a good place only for those who were poor. When conversing with a group of young men in the camp they made this evident:

Alam: Life in the camp is bad.

Babu: It's bad but...

Rayhan: Life in the camp is bad but it's good for us. You will not be able to live here.

Researcher: You are saying life in camp is bad but still good for you. How so?

Alam: We have been living here since we were kids. We like living here.
Rayhan: If we stay outside [the camp] house rent would be 10,000 takas. I earn 6,000 takas. Then how will I manage it? So, we are quite happy here.

Such claims are not very different from the way residents of a stigmatised low-income town in South Wales assert that "it's not that bad" (Thomas, 2016, p. 5) or the residents of a favela in Brasilia declare that "here it is heaven! It is mother's lap" (Araújo \& Costa, 2017, p. 158). As Lomax (2015) points out, by producing such counternarratives the urban poor do not necessarily present a false view of their neighbourhood or misrepresent it as something that it is not. Likewise, in Korail and Town Hall Camp, the residents were acutely aware of the illegality/informality of their neighbourhood and the numerous problems and challenges that constituted the everyday reality of living in such places. Due to this awareness they often accepted and internalised the meanings of dominant, stigmatising discourses. However, they also discursively resisted such discourses by producing counternarratives about their neighbourhoods. These placebased narratives were rooted in shared experiences of everyday practices and associational life in neighbourhoods that are deeply discredited. These serve to legitimise informal settlement residents' claim to the city, allow negotiating with authorities for gaining access to services, and create solidarities for resistance against eviction drives. More importantly, these narratives discursively resist the marginalizing effects produced by the hegemonic narratives constructed by state apparatuses.

\section{Conclusion}

In many cities, public officials, city authorities, urban planners, media and the affluent and middle-classes constantly and selectively present informal settlement residents as illegal, criminal, and illegitimate members of the wider city. This is done discursively and through various direct coercive measures of exclusion and intimidation, and underdevelopment. Our findings show that while residents of the study sites accepted and internalised the stigmatising narratives, they also resisted them by producing counternarratives of a good place for the urban poor. People living in stigmatised locations are no different to others who deal with challenging circumstances. As a way of individual and collective survival, they frequently vacillate between competing discourses about their identities in relation to their communities and their cities and in response to different audiences.

This may appear as contradictory to Wacquant's $(2007,2008)$ theorisation of how people living in discredited neighbourhoods respond to territorial stigma. As Jensen and Christensen (2012) point out, contradictions arise when the attempt is made to universalise Wacquant's theories whereas he himself emphasised the importance of national and local contexts. People produce new spatial meanings and narratives about their neighbourhood through everyday interactions and vari- 
ous exchanges which are often shaped by a city's sociopolitical and cultural processes and structures. The placebased grassroots narratives of informal settlements that the urban poor produce, contrast sharply with those produced and imposed by the city's elites. As this article shows, the insider accounts from Korail and Town Hall Camp residents present different imaginings of these neighbourhoods that refute the dominant narratives imposed by urban elites. These counternarratives offer the possibility of discursive resistance by urban informal settlement residents against territorial stigma. At the same time, they are instructive in recognising the elements such as affordable housing, safety, and associational life that disadvantaged urban populations in Dhaka regard as essential for a good life in the city.

In this article, we examined residents' subjective experience and response to territorial stigma in two informal settlements in Dhaka. Dhaka is a city with nearly 4,000 informal settlements. Although we would expect to find similar competing discourses across many of these places, and these discourses resonate with other stigmatised places in the literature, they are highly diverse in terms of socio-economic conditions, location and population dynamics. Their residents are likely to experience and respond to territorial stigma in varied ways. Further research focus from urban scholars, both at the local and global levels, towards Dhaka's informal settlements would allow for further theoretical generalisation about the territorial stigma in the context of Southern megacities.

\section{Acknowledgments}

We express our gratitude to the residents of Korail and Town Hall Camp who participated in this study. We thank the two anonymous reviewers who provided comments on an earlier version of this article which significantly enriched its content. We are grateful to the board of Studio for International Development, Amsterdam, for their generous support to cover the article processing charge which made open access publication of this article possible.

\section{Conflict of Interests}

The authors declare no conflict of interests.

\section{References}

Ahmed, I. (2014). Factors in building resilience in urban slums of Dhaka, Bangladesh. Procedia Economics and Finance, 18, 745-753.

Araújo, S. H. d., \& Costa, E. B. d. (2017). From social hell to heaven? The intermingling processes of territorial stigmatisation, agency from below and gentrification in Varjão, Brazil. In P. Kirkness \& A. TijéDra (Eds.), Negative neighbourhood reputation and place attachment: The production and contestation of territorial stigma (pp. 172-191). New York, NY: Routledge.

August, M. (2014). Challenging the rhetoric of stigmatization: The benefits of concentrated poverty in Toronto's Regent Park. Environment and Planning A: Economy and Space, 46(6), 1317-1333.

Auyero, J. (1999). 'This is a lot like the Bronx, isn't it?' Lived experiences of marginality in an Argentine slum. International Journal of Urban and Regional Research, 23(1), 45-69.

Bertuzzo, E. T. (2016). The multifaceted social structure of an unrecognised neighbourhood: Experience from Karail basti. In M. Rahman (Ed.), Dhaka: An urban reader. Dhaka: The University Press Limited.

Bhan, G. (2014). The impoverishment of poverty: Reflections on urban citizenship and inequality in contemporary Delhi. Environment and Urbanization, 26(2), 547-560.

Blokland, T. (2008). "You got to remember you live in public housing": Place-making in an American housing project. Housing, Theory and Society, 25(1), 31-46.

Bork-Hüffer, T., Etzold, B., Gransow, B., Tomba, L., Sterly, H., Suda, K., . . . \& Flock, R. (2016). Agency and the making of transient urban spaces: Examples of migrants in the city in the Pearl River Delta, China, and Dhaka, Bangladesh. Population, Space and Place, 22(2), 128-145.

Butler, A. (2019). Toxic Toxteth: Understanding press stigmatization of Toxteth during the 1981 uprising. Journalism. https://doi.org/10.1177/ 1464884918822666

Caldeira, T. P. R. (2000). City of walls: Crime, segregation, and citizenship in São Paulo. Berkeley, CA: University of California Press.

Clarke, J., Newman, J., Smith, N., Vidler, E., \& Westmarland, L. (2007). Creating citizen-consumers: Changing publics and changing public services. Thousand Oaks, CA: Sage.

Creswell, J. W. (2007). Qualitative inquiry \& research design: Choosing among five approaches. Thousand Oaks, CA: Sage.

Dados, N., \& Connell, R. (2012). The Global South. Contexts, 11(1), 12-13.

Gama, Y. K. (2018). Cidade alta: Histórias e memórias da remoção e a construção do estigma de favela num conjunto habitacional [Upper city: Stories and memories of the removal and construction of slum stigma in a housing estate]. Planning Perspectives, 33(3), 479-480.

Geiselhart, K. (2017). Call it by its proper name! Territoryism and territorial stigmatisation as a dynamic model: The case of Old Naledi. In P. Kirkness \& A. TijéDra (Eds.), Negative neighbourhood reputation and place attachment: The production and contestation of territorial stigma (pp. 216-234). New York, NY: Routledge.

Ghertner, D. A. (2008). Analysis of new legal discourse behind Delhi's slum demolitions. Economic and Political 
Weekly, 43(20), 57-66.

Ghertner, D. A. (2010). Calculating without numbers: Aesthetic governmentality in Delhi's slums. Economy and Society, 39(2), 185-217.

Goffman, E. (1963). Stigma: Notes on the management of spoiled identity. Englewood Cliffs, NJ: PrenticeHall.

Hasan, K. (2018, May 29). The Tk50 crore drug empire run from a Mirpur slum. Dhaka Tribune. Retrieved from https://www.dhakatribune.com/bangladesh/ crime/2018/05/29/the-tk50-crore-drug-empirerun-from-a-mirpur-slum

Hastings, A. (2004). Stigma and social housing estates: Beyond pathological explanations. Journal of Housing and the Built Environment, 19(3), 233-254.

Hossain, S. (2013). The informal practice of appropriation and social control-Experience from a bosti in Dhaka. Environment \& Urbanization, 25(1), 209-224.

Ingen, C. v., Sharpe, E., \& Lashua, B. (2018). Neighborhood stigma and the sporting lives of young people in public housing. International Review for the Sociology of Sport, 53(2), 197-212.

Jahan, M. (2012). Impact of rural urban migration on physical and social environment: The case of Dhaka city. International Journal of Development and Sustainability, 1(2), 186-194.

Jensen, S. Q., \& Christensen, A. (2012). Territorial stigmatization and local belonging: A study of the Danish neighbourhood Aalborg East. City, 16(1/2), 74-92.

Keene, D. E., \& Padilla, M. B. (2014). Spatial stigma and health inequality. Critical Public Health, 24(4), 392-404.

Khan, M. J. (2013, July 27). City slums den for crimes. Dhaka Tribune. Retrieved from https://www. dhakatribune.com/uncategorized/2013/07/27/cityslums-den-for-crimes

Lata, L., Walters, P., \& Roitman, S. (2019). A marriage of convenience: Street vendors' everyday accommodation of power in Dhaka, Bangladesh. Cities, 84, 143-150.

Lindemann, H. (2001). Damaged identities, narrative repair. Ithaca, NY: Cornell University Press.

Local Government Division. (2014). National urban policy 2014 (National Policy Draft). Dhaka: Bangladesh Ministry of Local Government, Rural Development and Co-Operatives.

Lomax, H. (2015). 'It's a really nice place to live!' The ethnographic encounter as a space of intergenerational exchange. In R. M. Vanderbeck \& N. Worth (Eds.), Intergenerational space (pp. 65-78). New York, NY: Routledge.

Mahmud, T. (2018, May 31). Kashem, the yaba kingpin of Korail. Dhaka Tribune. Retrieved from https:// www.dhakatribune.com/bangladesh/crime/2018/ 05/31/kashem-the-yaba-kingpin-of-korail

Moser, C. O. N. (2004). Urban violence and insecurity: An introductory roadmap. Environment \& Urbanization, 16(2), 3-16.
Muñoz, S. M., \& Maldonado, M. M. (2012). Counterstories of college persistence by undocumented Mexicana students: Navigating race, class, gender, and legal status. International Journal of Qualitative Studies in Education, 25(3), 293-315.

Ong, A. (2011). Introduction: Worlding cities, or the art of being global. In A. Roy and A. Ong (Eds.), Worlding cities: Asian experiments and the art of being global (pp. 1-25). Malden, MA: Wiley-Blackwell.

Osborne, K., Ziersch, A., \& Baum, F. (2011). Perceptions of neighbourhood disorder and reputation: Qualitative findings from two contrasting areas of an Australian city. Urban Policy and Research, 29(3), 239-256.

Palmer, C., Ziersch, A., Arthurson, K., \& Baum, F. (2004). Challenging the stigma of public housing: Preliminary findings from a qualitative study in South Australia. Urban Policy and Research, 22(4), 411-426.

Parker, D., \& Karner, C. (2010). Reputational geographies and urban social cohesion. Ethnic and Racial Studies, 33(8), 1451-1470.

Popay, J., Thomas, C., Williams, G., Bennett, S., Gatrell, A., \& Bostock, L. (2003). A proper place to live: Health inequalities, agency and the normative dimensions of space. Social Science \& Medicine, 57(1), 55-69.

Rahman, H. Z. (Ed.). (2012). Bangladesh urban dynamics. Dhaka: Power and Participation Research Centre.

Sanyal, R. (2014). Urbanizing refuge: Interrogating spaces of displacement. International Journal of Urban and Regional Research, 38(2), 558-572.

Siddiqui, K., Ahmed, J., Siddique, K., Huq, S., Hossain, A., Nazimud-Doula, S., \& Rezawana, N. (2010). Social formation in Dhaka, 1985-2005: A longitudinal study of society in a third world megacity. Farnham: Ashgate.

Slater, T. (2017). Territorial stigmatization: Symbolic defamation and the contemporary metropolis. In J. Hannigan \& G. Richards (Eds.), The Sage handbook of new urban studies (pp. 111-125). London: Sage.

Slater, T., \& Anderson, N. (2012). The reputational ghetto: Territorial stigmatisation in St Paul's, Bristol. Transactions of the Institute of British Geographers, 37(4), 530-546.

Smith, C. B. R. (2010). Socio-spatial stigmatization and the contested space of addiction treatment: Remapping strategies of opposition to the disorder of drugs. Social Science \& Medicine, 70(6), 859-866.

Suykens, B. (2017). The past, present and future of slum property regimes in Chittagong, Bangladesh. South Asia: Journal of South Asian Studies, 40(1), 146-161.

Thomas, G. M. (2016). 'It's not that bad': Stigma, health, and place in a post-industrial community. Health Place, 38, 1-7.

Tyler, I. (2013). Revolting subjects: Social abjection and resistance in neoliberal Britain. London: Zed Books.

Tyler, I., \& Slater, T. (2018). Rethinking the sociology of stigma. The Sociological Review Monographs, 66(4), 721-743.

UN-Habitat. (2015). Informal settlements (Habitat III Is- 
sue Papers No. 22). New York, NY: UN-Habitat. Retrieved from http://unhabitat.org/habitat-iii-issuepapers-22-informal-settlements

Wacquant, L. J. D. (2007). Territorial stigmatization in the age of advanced marginality. Thesis Eleven, 91(1), 66-77.

Wacquant, L. J. D. (2008). Urban outcasts: A comparative sociology of advanced marginality. Malden, MA: Polity.

Warr, D. J. (2005). There goes the neighbourhood: The malign effects of stigma. Social City, 19, 1-11.
Warr, D. J. (2016). Social networks in a 'discredited' neighbourhood. Journal of Sociology, 41(3), 285-308.

Worldmap. (n.d.). Dhaka map. World Map. Retrieved from https://www.worldmap1.com/map/ bangladesh/dhaka-map.asp

Zhang, Y. (2017). "This is my 'Wo"': Making home in Shanghai's lower quarter. In P. Kirkness \& A. TijéDra (Eds.), Negative neighbourhood reputation and place attachment: The production and contestation of territorial stigma (pp. 138-157). New York, NY: Routledge.

\section{About the Authors}

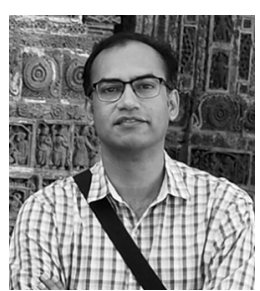

Kazi Nazrul Fattah is a Doctoral Candidate at the School of Social Science, The University of Queensland, Australia. His research interests include socio-political dynamics of urbanization in the Global South, urban governance and public policy, civic engagement, and gender-based violence. His current research explores the circulations of power and modes of governance in urban informal settlements in Bangladesh.

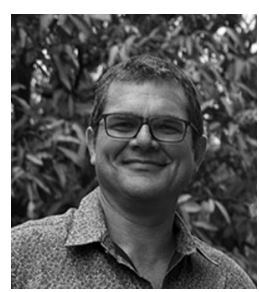

Peter Walters (PhD) is an Urban Sociologist who teaches and researches in the School of Social Science at The University of Queensland, Australia. His work focuses on the intersection of public space and the public realm, urban community and effects of abstract capital on urban social relations. He has also researched the way that urban community and formal institutions can work to create and obstruct resilience in disasters. 